Dragana Rogić

Arheološki institut Beograd

rogic.dragana@gmail.com

Darko Despotović

konzervator

Bebina Milovanović

Arheološki institut Beograd

UDK 904:75.052"652"(497.11);

902.2(497.11)"2003/2004"

Izvorni naučni članak

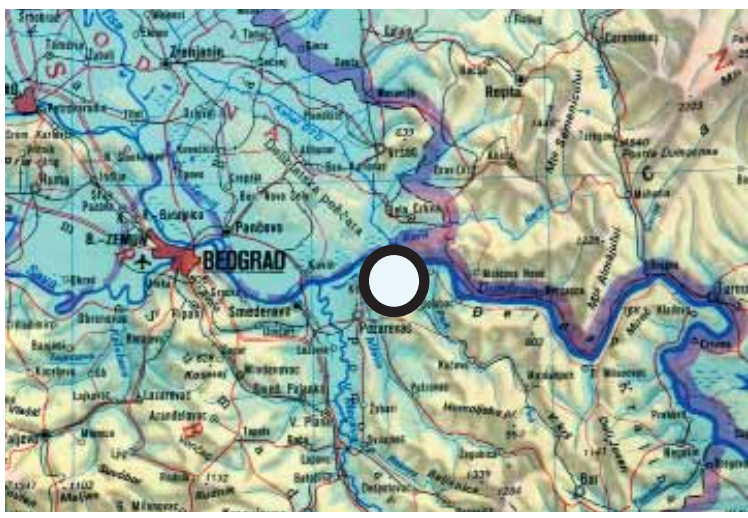

Viminacium, Stari Kostolac, Srbija

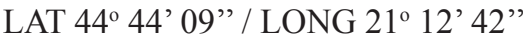

\title{
FRAGMENTI ZIDNOG SLIKARSTVA SA TERMI IZ VIMINACIJUMA
}

\begin{abstract}
APSTRAKT
Sistematska arheološka iskopavanja termi na Viminacijumu dopunjuju naša saznanja o životu antičkog grada. Novac nađen u pristoriji 1 i 2 , datuje mlađu fazu termi iz druge polovine III veka, kada je objekat proširen dodavanjem novih bazena i pomoćnih prostorija.

Ostaci zidnog slikarstva otkriveni u prostoriji 1 sugerišu način unutrašnjeg dekorisanja javnih zgrada. Konzervatorskim postupkom pojedini fragmenti su postavljeni na novi malterni nosač. Sačuvane ostatke fresaka nije bilo moguće potpuno rekonstruisati, već samo stabilizovati i od njih napraviti više prenosivih eksponata.
\end{abstract}

KLJUČNE REČI: KONZERVACIJA, TERME, FRAGMENTI, SPAJANJE, MALTER, REKONSTRUKCIJA.

\section{UVOD}

Sistematska arheološka iskopavanja na javnim, gradskim termama u Viminacijumu započeta su u julu 2003. godine i trajala su samo mesec dana. Iskopavanja većeg obima nastavljena su naredne godine i trajala su od maja do kraja novembra. Tom prilikom otkriven je najveći deo rimskog kupatila na kome se povremeni arheološki i konzervatorski radovi još uvek izvode. Terme, očuvane u nivou hipokausta, dozvoljavaju praćenje više građevinskih faza u dužem hronološkom periodu od kraja I do sredine V veka. Pored osnovnih bazena za kupanje u toploj (caldarium - konhe I, II, IV, V) i hladnoj vodi (frigidarium - konha III), istraženo je još nekoliko prostorija različitih po obliku i nameni.
O raskoši i umetničkom nadahnuću svedoče oslikani zidovi prostorije $1^{1}$. Naime, u severozapadnom delu termi konstatovane su dve pravougaone prostorije zidane od lokalnog kamena „zelenca“, 2 prilikom čijih iskopavanja se u prostoriji broj 1, u sloju šuta (fragmenti opeka,

1. Prostorija je tako naznačena u terenskoj dokumentaciji. 2. Pod pojmom ,zelenac“ podrazumeva se kamen iz lokalnog kamenoloma u Ramu, tj. iz rimske Lederate, odakle je dovožen građevinski materijal za izgradnju Viminacijuma. Zelenac, odnosno, zeleni škriljac pripada velikoj grupi, mahom ortometamorfnih stena, nastalih pod sličnim uslovima. Zajednička im je škriljava tekstura, dok im struktura zavisi od preovlađujućih minerala i može da bude granoblastična, lepidoblastična i nematoblastična. Najvažniji minerali koji se u njima pojavljuju su epidot, hlorit, albit, talk, amfiboli, kvarc i dr. Ime dobijaju prema mineralnom sastavu (hloritski, albitski, talkni). 


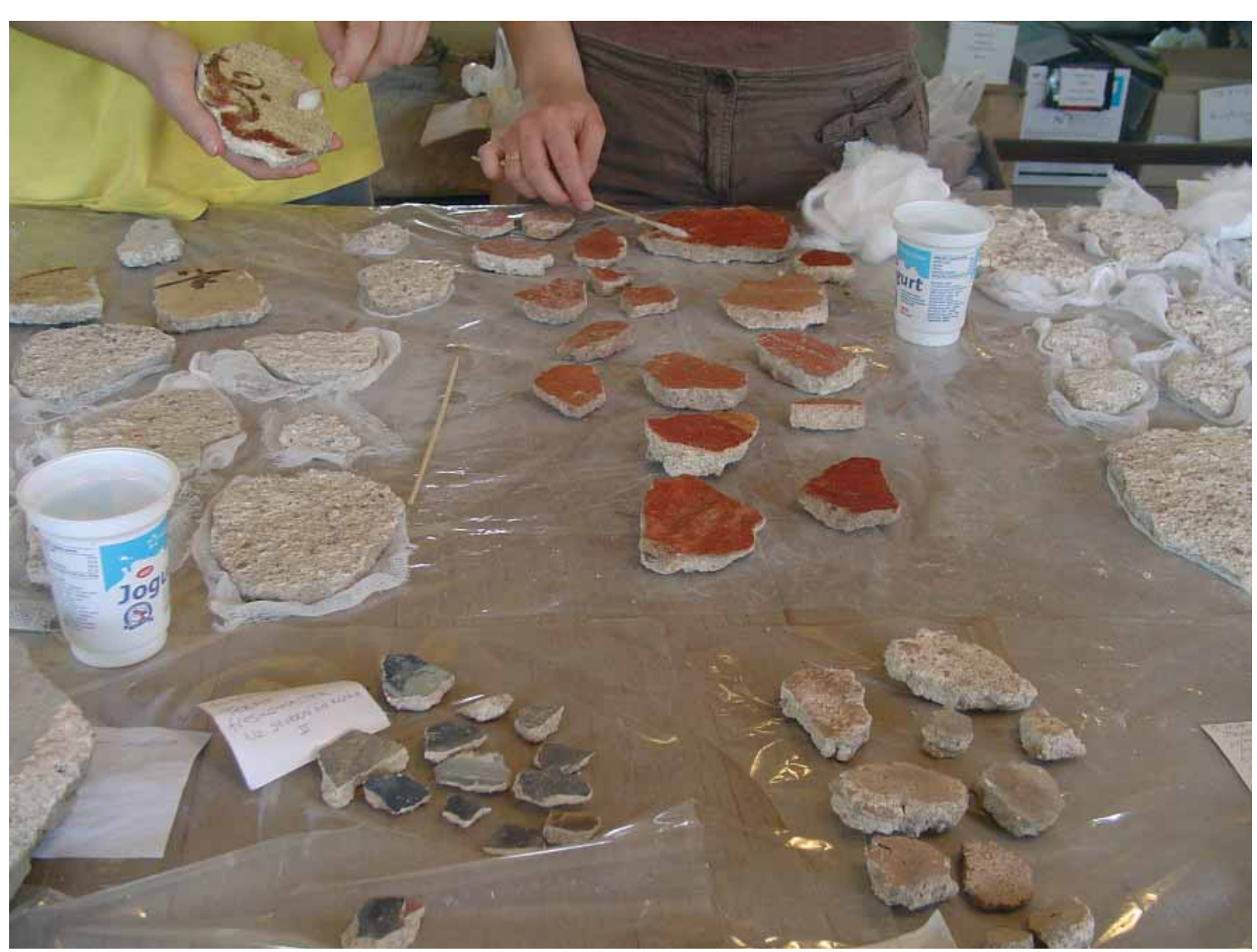

sl. 1.čišćenje fragmenata fresaka čije su poleđine iznivelisane postupkom opisanim u tekstu

kamena peščara i zelenca, maltera i sitnozrnog žutog peska), na koti od 79,78 m naišlo na prve fragmente zidnog slikarstva. Dimenzije spoljnih zidova prostorije su $6,85 \times 4,85 \mathrm{~m}$. Širina zidova varira od 0,65 do $0,77 \mathrm{~m}$. Prostorija je sačuvana $\mathrm{u}$ nivou ispod poda, sa visinom zidova od 3,55 m, dok je sama podnica bila probijena.

Ostaci fragmenata opeka i heksagonalnih, leptirastih i pravougaonih keramičkih podnih pločica svedoče da je pod verovatno bio popločan ovim materijalom, dok su podnu substrukciju činili sitnozrni pesak, zemlja i malter.

O nameni prostorije svedoči otkriveni kanal sagrađen od kamena zelenca i opeka povezanih malterom. Dimenzije kanala su 5 × 2 m, a očuvana visina $2,20 \mathrm{~m}$. Kanal je u obliku ćiliričnog slova $P$, sa zidovima širine oko $0,70 \mathrm{~m}$.

Na severnom zidu konstatovan je naknadno zazidan zasvedeni prolaz kao i manji lučno zasveden otvor ozidan opekama. U južnom zidu uočena su dva manja lučno zasvedena otvora simetrična u odnosu na one u severnom zidu, a u zapadnom još jedan lučno zasveden otvor koji vodi do sledeće prostorije, do sada neistražene. Veličine lučno zasvedenih otvora variraju i prosečnih su dimenzija oko $0,50 \times 0,42 \mathrm{~m}$. Simetrično su postavljeni, a kroz njih su prolazile keramičke cevi za dovod vode, ali i zagrevanje prostorije broj 2 koja se nadovezuje na istočni zid. U njoj se nalaze stubovi od opeka, odnosno hipokaust.

Neki od lučnih otvora su naknadno zazidani, verovatno kada su odaje izgubile svoju prvobitnu namenu, odnosno korišćene su u druge svrhe kada sistem podnog grejanja više nije bio u funkciji. Fragmenti cevi nađeni su u šutu tokom iskopavanja. Otkriveni kanal unutar prostorije broj 1, definiše namenu odaje. Naime, ona je bila $\mathrm{u}$ funkciji latrine, $\mathrm{tj}$. toaleta.

Nalazi fragmenata zidnog slikarstva iz ove prostorije svedoče da su zidovi iznad podnice bili oslikani. Pokretni arheološki materijal je raznovrstan, ali ne i tako brojan. Pored fragmenata različitih keramičkih i staklenih posuda, nađene su koštane ukosnice, olovne i bronzane oplate, gvozdeni klinovi i amorfni komadi gvozdene zgure. Najznačajniji nalazi koji hronološki determinišu prostoriju, svakako su četiri bronzana novčića. Novac je pod velikom patinom i uglavnom neči- 


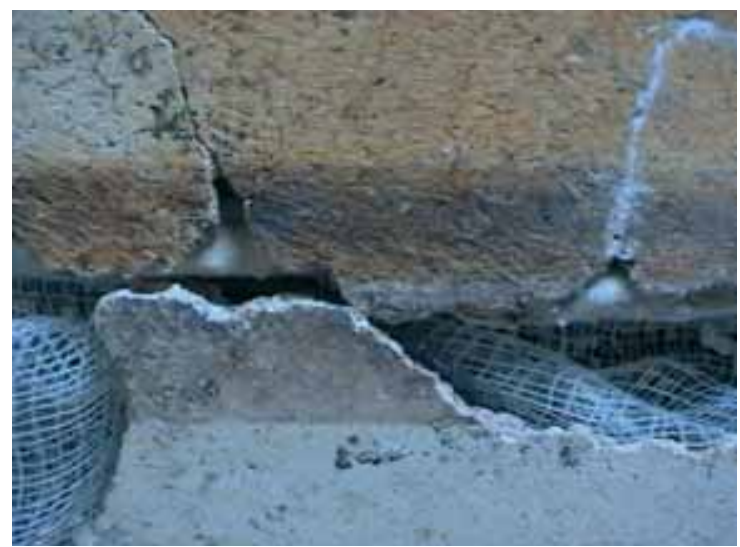

sl. 2. Spajanje fragmenata po slikanom motivu

tak. Po obliku se može datovati u drugu polovinu trećeg veka. Novac nađen tokom iskopavanja unutar prostorije broj 2 koja pripada istoj građevinskoj i hronološkoj fazi je brojniji. Najraniji primerak pripada periodu vladavine Septimija Severa (193-211), dok su ostali primerci iz sredine ili s kraja III veka. Poznat je po jedan primerak bronzanog novca Gordijana III sa suprugom Trankvilinom sa natpisom na grčkom (238-244), zatim Valerijana (253-260), Galijena (253-268) i Klaudija II Gotskog (268-270). Pronađeno je čak 18 bronzanih novčića Aurelijana (270-275) kovanih u tri različite kovnice: Siscija, Mediolanum i Kizik. Devetnaesti primerak je iskovan u čast njegove supruge Severine. Iz perioda vladavine cara Proba (276-282) potiče šest novčića, dok jedan pripada vladavini Karusa (282-283), a dva su iz vremena Maksiminusa (286-305). Najmlađi novac pripada Konstantinu II (341-346), a u IV vek su datovana dva slepljena i korozijom oštećena novčića.

$\mathrm{Na}$ osnovu nalaza novca, obe prostorije bi pripadale kasnijoj fazi termi, tj. drugoj polovini III veka, kada su po svoj prilici prvobitne terme proširene dodavanjem bazena III i V i pomoćnih prostorija (svlačionice, toalet, vežbaonice i sl.).

Verovatno se ova obnova desila u vreme cara Aurelijana kako to pokazuju brojni primerci novca iz perioda njegove vladavine nađeni u prostoriji broj 2.

Iskopavanja unutar prostorije 1 su završena na relativnoj dubini od oko $3,55 \mathrm{~m}$, tj. do nivoa opekom popločanog poda.

Fragmenti zidnog slikarstva su deponovani u arheološki centar na prostoru TE Drmno.

U aprilu 2007. godine započeti su konzervatorsko radovi na fragmentima.

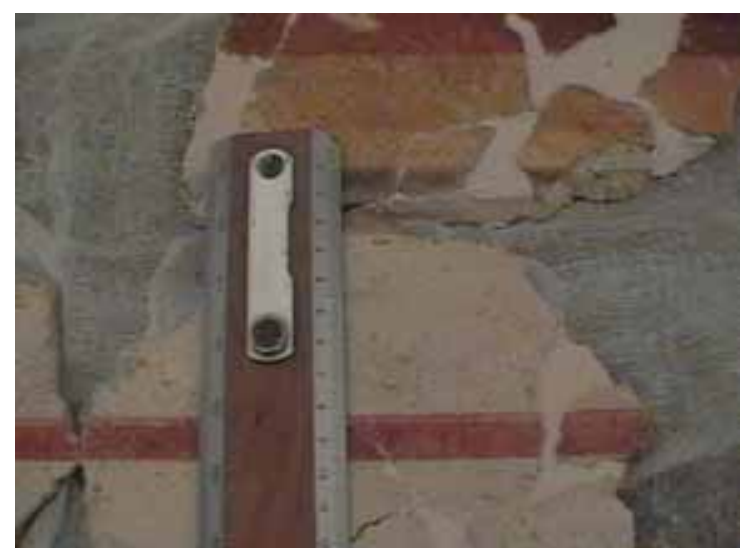

sl. 3. Nivelisanje fragmenata u pesku, pre nanošenja maltera

\section{RADOVI NA FRAGMENTIMA FRESAKA SA TERMI}

Konzervatorski radovi obuhvatali su spajanje fragmenata i njihovo postavljanje na novi nosač. Od postojećih fragmenata nije bilo moguće potpuno rekonstruisati likovnu celinu jer je nedostajao veći deo slikane površine. Radovi su tekli ovim tokom: čišćenje; fiksiranje; dokumentovanje; zaštita lica fragmenata flasterima gaze i adekvatnim lepkom da ne bi došlo do dodatnih oštećenja jer je poleđina fragmenata morala da se obradi; ojačavanje maltera; razvrstavanje fragmenata po boji, slikanom motivu i malteru; spajanje fragmenata i izrada novog nosača.

Faze rada:

Fragmenti su prvo očišćeni suvom mekanom četkom, zatim su hirurškim skalpelima mehanički uklonjene veće naslage zemlje. Nakon ove faze pristupilo se čišćenju fragmenata pamučnim tuferima i destilovanom vodom. Postupak čišćenja ponavljan je nekoliko puta sve dok u potpunosti nisu uklonjene naslage nečistoća.

Bojeni sloj je uglavnom bio stabilan i nije bilo većih problema prilikom čišćenja, sem što se na pojedinim fragmentima otirala crvena boja. Posle čišćenja fragmenti su ostavljeni nekoliko dana da se dobro osuše, a zatim je urađeno fiksiranje sa 3\% rastvorom Paraloida B72 u acetonu. Fiksiranje je urađeno dva puta, a fiksativ je nanošen finom četkom.

Nakon fiksiranja fragmenti su razvrstani kako bi se utvrdilo da li mogu da se spoje u jednu celinu. Osnovni metod za grupisanje bilo je uklapanje po slikanom motivu, ali su i sama struktura 
i sastav maltera mogli da ukažu na to koji delovi gde pripadaju.

Debljina maltera bila je različita i kretala se od 1 do 15 centimetara, zbog čega je bilo neophodno da se ona izjednači na debljinu od $1-3 \mathrm{~cm}$. Fragmenti su sa lica zaštićeni flasterima gaze da ne bi došlo do dodatnog pucanja prilikom istanjivanja. Za lepak je korišćena karboksi-metil celuloza i 10\% tutkalo u razmeri 1:1. Svaki sloj gaze i lepka se sušio 24 časa. Za istanjivanje maltera korišćena je rotaciona žičana četka koja je bila postavljena na stubnu bušilicu. Kada su istanjeni svi fragmenti urađeno je ojačavanje maltera krečno kazeinskim akrilnim vezivom.

Napravljen je drveni ram sa dnom, dimenzija 120 x $120 \mathrm{~cm}$, u koji je stavljen pesak radi lakšeg nivelisanja i spajanja fragmenata.

Za pravljenje maltera korišćeno je mermerno brašno i krečno-kazeinsko, akrilno vezivo. Gaza je u prvim slojevima maltera služila kao armatura, kako bi veza sa spojenim delovima bila čvršća, postavljana je u trakama $10 \mathrm{~cm}$ širine. Trake su postavljene tako da se svaka preklapa po nekoliko centimatara sa narednom.

Fragmenti su nivelisani u pesku, a kada je tačno određeno njihovo mesto povezani su malterom. Za sušenje maltera bilo je potrebno 10 dana da bi celina mogla dalje da se obrađuje, a da ne dođe do razdvajanja spojenih delova. Malter je nanošen u dva sloja $0,5 \mathrm{~cm}$ niže od bojenog sloja. Manje celine koje su bile sastavljene, nakon očvršćivanja maltera, postavljene su licem na dole da bi se nastavilo sa obradom poleđine. Posle sušenja nanešen je još jedan sloj maltera debljine oko 0,5

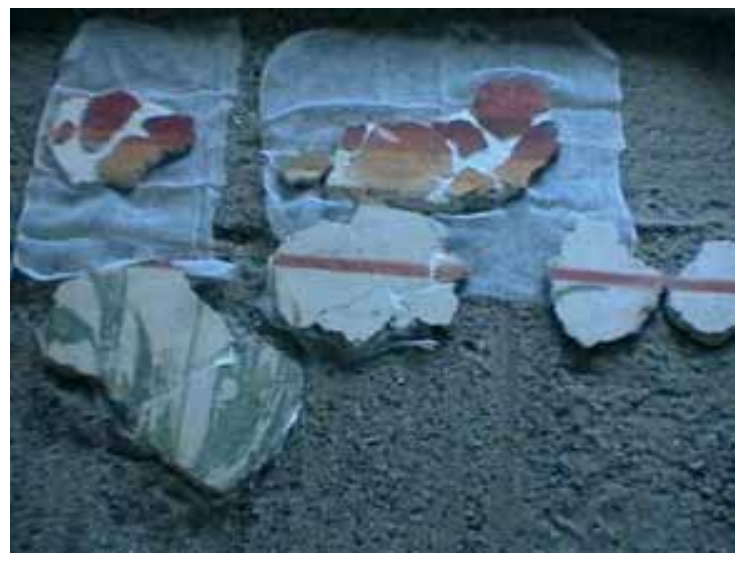

slika 4. spajanje fragmenata u pesku, prvo su spojene manje celine koje su se kasnije uklapale u konačnu celinu $\mathrm{cm}$, ali prethodno je oko fragmenata postavljen pravougaoni kalup koji je davao konačnu formu nosača. Sve manje celine imaju tri sloja gaze i tri sloja maltera sa poleđine. Kada je završena obrada malternog nosača i kada se sve dobro osušilo (20 dana), sastavljene celine su obrađivane sa lica i tada je nanešen završni sloj maltera. Pre ovog završnog sloja, površina suvog maltera je navlažena vezivom. Za završni sloj maltera korišćeno je prosejano mermerno brašno i nešto slabije vezivo da ne bi došlo do pucanja završnog sloja maltera.

Ovim postupkom urađeno je šest nosača: $\mathrm{N} 1-34$ x $59 \mathrm{~cm}, \mathrm{~N} 2-26,5 \times 35 \mathrm{~cm}, \mathrm{~N} 3-30$ x $42 \mathrm{~cm}, \mathrm{~N} 4-33,5$ x $50 \mathrm{~cm}, \mathrm{~N} 5-24$ x $43 \mathrm{~cm}$ i N6 $-24,5 \times 50,5 \mathrm{~cm}$.

Nosač-N7 $(56$ x $94 \mathrm{~cm})$ je zbog svojih dimenzija imao drugačiji tretman. Fragmenti su gupisani u manje celine koje su spajane u pesku, za prve slojeve maltera korišćena je gaza kao armatura (kao što je već opisano u tekstu), zatim su manje spojene celine uklapane sa drugim i nivelisane. Kada su celine postavljene na svoje mesto, vezane su malterom. Posle sušenja maltera urađeno je ojačavanje lica freske sa pet slojeva gaze $\mathrm{i}$ lepkom od karboksi-metil celuloze i tutkala.

Kada se sve ovo dobro osušilo nosač je podignut i okrenut na poleđinu, na ravnu podlogu preko koje je bila postavljena sunđerasta substruktura i melineks da ne bi došlo do nekih oštećenja na licu freske. Urađeno je nivelisanje poleđine dodavanjem maltera da bi se dobila ravna površina na koju se mogu dalje nanositi slojevi maltera da bi se formirao nosač freske. Nanešena su još dva sloja maltera. Posle sušenja maltera cela površina

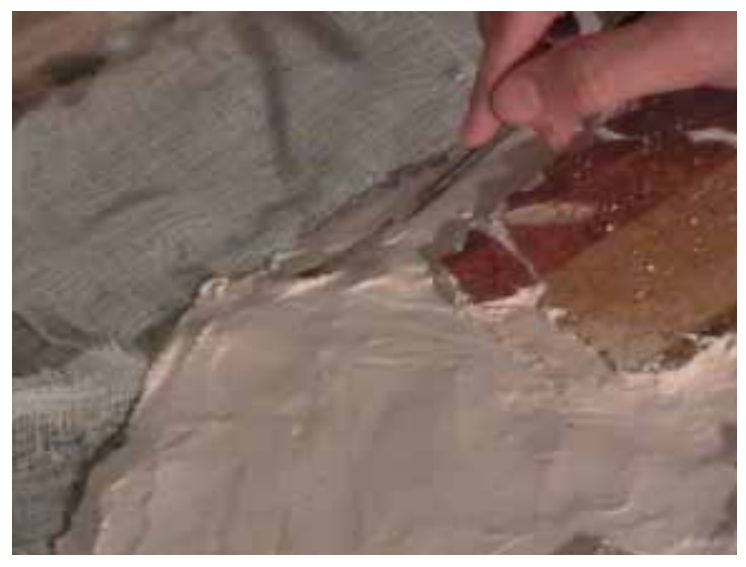

slika 5. nanošenje maltera 


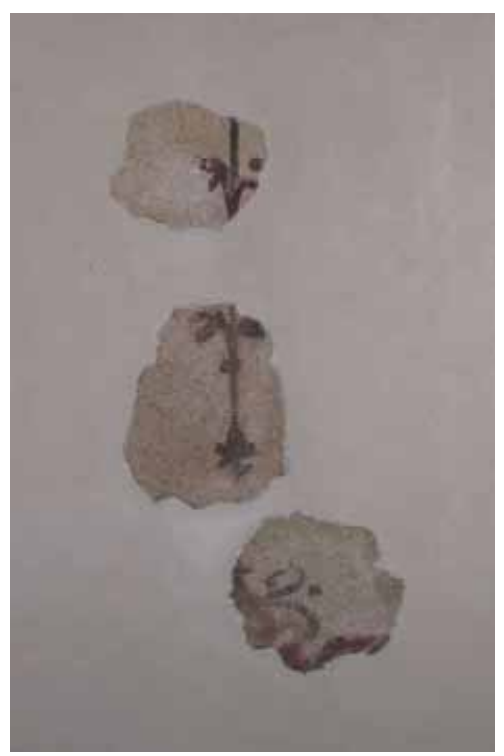

sl. 6. N-1, slikani motiv rađen ljubičasto-crvenkastom bojom

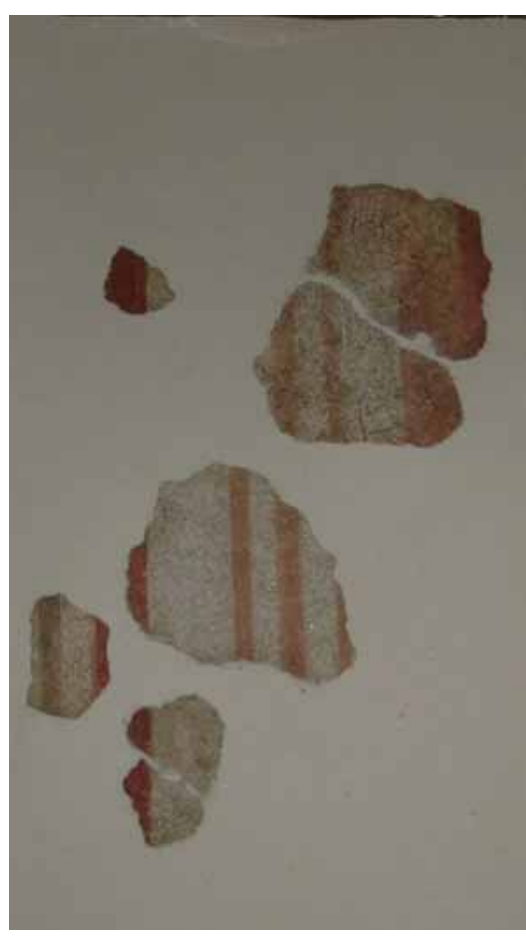

sl. 9. N-4

širina sivkasto-ljubičaste bordure je 1 $\mathrm{cm}$; širina najtanje svetlo crvene bordure je $8 \mathrm{~mm}$; deblja crvena bordura je $1 \mathrm{~cm}$ široka; najdeblja lazurno crvena je $3,3 \mathrm{~cm}$;

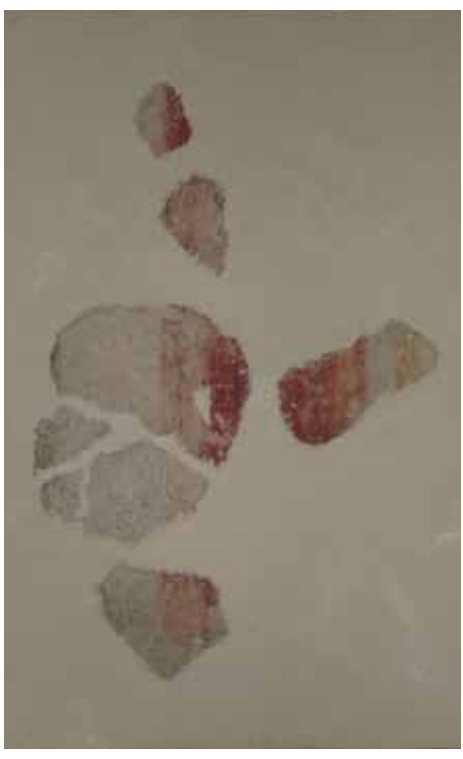

sl.7. N-2 Na beloj pozadini prikazana je sivkasta bordura, $\mathrm{u}$ centralnom delu se nalazi valerski građena bordura u čijem se središnjem delu nalazi tamno crveni pojas, a sasvim desno nalazi se žuta bordura.

je impregnirana dvokomponentnim premazom za impregnaciju „Policem prajmer A i B,, u razmeri 1:1. Nakon sušenja premaza koje po preporuci proizvođača traje od 24 do 72 sata, nanešen je još jedan sloj na koji je odmah potom postavljena plastična mrežica zaštićena istim premazom sa dodatkom mermernog brašna. Posle sušenja ovog sloja maltera, postavljen je završni sloj maltera od mermernog brašna krupnije granulacije i krečno-kazeinsko-akrilnog veziva. Posle sušenja ova celina je okrenuta na lice, kada je postavljen dekorativni malter nekoliko milimetara ispod bojenog sloja.

Restauracija ovih celina još uvek nije završena. Samo je na celini N5 početa restauracija, a odlučili smo da se tačno vidi rekonstrukcija i da posmatraču bude jasno koji su delovi restaurirani.

\section{ZAKLJUČAK}

Radovi su tekli bez neočekivanih situacija. Ovaj poduhvat zahtevao je strpljiv rad koji je trajao tri meseca. Ono što sledi je restauracija i uramljivanje spojenih celina adekvatnim ramovima sa poleđinom.

Od postojećih fragmenata nije bilo moguće potpuno rekonstruisati likovnu sadržinu. Fragmenti koji nisu mogli da se uklope ni u jednu celinu sačuvani su i čekaju nova iskopavanja.

Nesumnjivo je da je slikana dekoracija veoma zanimljiva jer ima dosta fragmenata sa linearnim motivima. Od boja pre- 


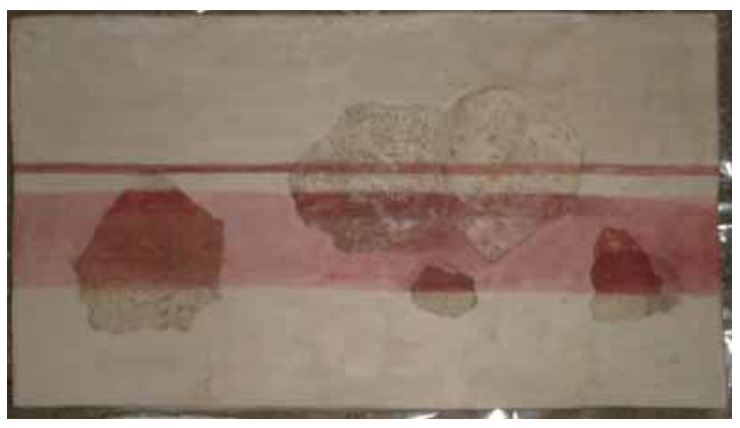

sl. 10. N-5 Na beloj pozadini prikazane su dve bordure, šira čija je širina $6 \mathrm{~cm}$, i uža čija je širina $7 \mathrm{~mm}$. Jedino je na ovom primeru urađena restauracija.

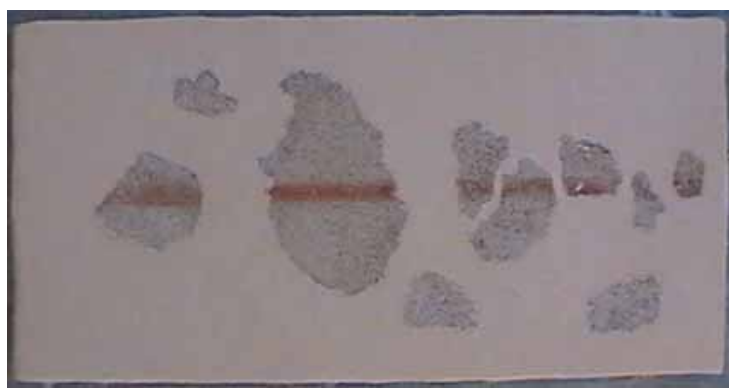

sl. 11. N-6 dimenzije ovog nosača su: 54 x $24 \mathrm{~cm}$, crvena bordura je $13 \mathrm{~mm}$

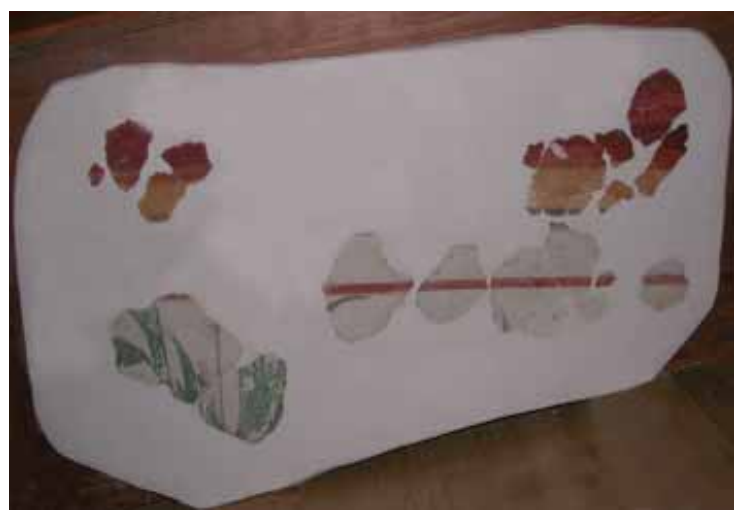

sl. 12. N-7 Ova slikana dekoracija ima više planova: u donjoj zoni predstavljen je floralni motiv zelene boje na krečno beloj pozadini maltera, iznad njega nalazi se bordura čija širina iznosi $13 \mathrm{~mm}$, gornja zona ove celine nastavlja se na belu pozadinu širine oko $5 \mathrm{~cm}$ (tanka crvena bordura je $13 \mathrm{~mm}$; žuta $5 \mathrm{~cm}$, a svetlocrvena oko $4 \mathrm{~cm})$

ovlađuju uglavnom nijanse crvene i ljubičaste, i plava, žuta i zelena boja. Posebna je celina sa floralnim motivima izvedenim zelenom bojom dok je za pozadinu iskorišćena krečno bela površina. Ovaj motiv se završava crvenom, horizontalnom bordurom na koju se nastavlja deo linearnog ta- kođe horizontalnog motiva, i to u nekoliko boja od sivkaste i žute do nekoliko nijansi crvene boje.

Malter većine fragmenata se sastoji od gašenog kreča, a kao punioc korišćen je šljunak različite granulacije. Neki od fragmenata imaju hidraulični malter. Poznato je da je takav malter po svojim svojstvima postojaniji na vlagu i otporniji na mehanička oštećenja. Fragmenti koji su u sastavu maltera imali i drobljenu opeku ili prah verovatno su bili u nižim zonama objekta ili u prostorijama u kojima je bila izražena vlažnost.

Fresko-tehnika se koristila za ukrašavanje zidnih površina različitih zdanja. Osim privatnih palata, javnih građevina, fresko-slikarstvo je našlo primenu i u sepulkralnoj arhitekturi. Otkriće više od dvadeset oslikanih grobnica na nekropolama Viminacijuma potvrđuje postojanje razvijene slikarske radionice u ovom gradu. ${ }^{3}$ Iako je do nedavno zidno-slikarstvo u profanoj arhitekturi Viminacijuma bilo nepoznato, nalazi fragmentarno sačuvanih fresaka sa gradskih termi unutar prostorije broj 1, odnosno latrine, potvrđuju postojanje slikarskih ateljea i umetnika koji su razvili osobenu slikarsku formu da bi kroz maštovitost svog izraza dostigli neprolaznost i univerzalnost izraženu na zidovima jednog termalnog objekta. Malobrojni i fragmentarno sačuvani ostaci zidnog slikarstva nisu nam, kao što je već rečeno, omogućili idealnu rekonstrukciju i zbog toga bi analogije bile samo hipotetičke. Nadamo se da će se radovi uskoro nastaviti i da će se prilikom novih arheoloških iskopavanja naći još oslikanih fragmenata koji će nam pomoći da u potpunosti rekonstruišemo slikanu dekoraciju ove prostorije i izvršimo poređenja sa identičnim primerima fresko slikarstva u rimskoj umetnosti. Do tada naše spojene celine čekaće u dobrim uslovima.

3. M. Korać, Slikarstvo Viminacijuma, Beograd, 2007. 


\section{LITERATURA}

\section{Korać 2007.}

Korać, M. 2007. Slikarstvo Viminacijuma, Beograd, Centar za nove tehnologije.

\section{FRAGMENTS OF WALL PAINTINGS DISCOVERED IN THERMAE FROM VIMINACIUM}

Systematic archaeological excavations of the Viminacium thermae enrich our knowledge about life in this ancient city. According to the coins found within rooms 1 and 2, the younger thermae phase can be dated into the second half of 3rd century, when the building was enlarged by adding new pools and auxiliary rooms.

The remains of fresco paintings discovered in room 1 reveal the way of decorating public buildings. The work done on fragments of wall decoration included conservation, documentation and presentation. The full reconstruction of the fresco remains was not possible. It was only possible to stabilize them and make several portable exibits.

KEY WORDS: CONSERVATION, THERMAE, FRESCO FRAGMENTS, CONNECTING, NIVELLATION, MORTAR, NEW CARRIER, RECONSTRUCTION. 


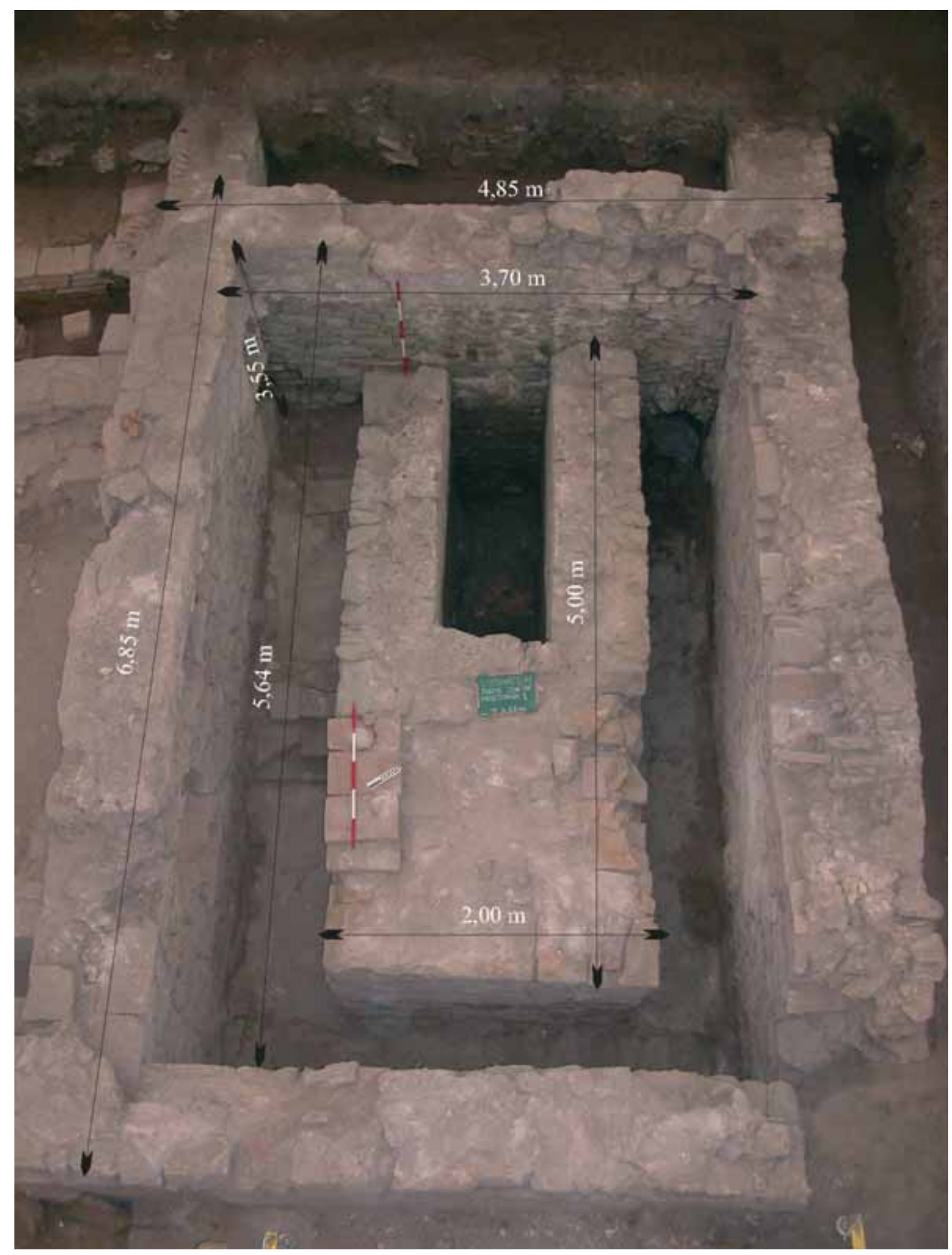

Slika 1. Prostorija broj 1. 